\title{
PRELIMINARY STUDIES ON AFFIRMATIVE
}

\author{
ACTION IN A BRAZILIAN UNIVERSITYY
}

\section{ESTUDOS PRELIMINARES SOBRE AÇÃO AFIRMATIVA EM UMA UNIVERSIDADE FEDERAL}

\section{EDUARDO DE SÃO PAULO}

Mestre em Psicologia Social e do Trabalho pelo Programa de Pós-Graduação em Psicologia Social, do Trabalho e das Organizações da Universidade de Brasília (UnB). Consultor da Canada School of Public Service e da Escola Nacional de Administração Pública. SQS 212, Bloco C, Sala 202, Brasília - DF - Brasil - CEP 70275-030

E-mail: eduardo.saopaulo@gmail.com

This article has benefited greatly from the thoughtful criticism of anonymous RAM reviewers. I thank Prof. Cláudio V. Torres for his patient guidance, as well as the following students who collaborated in the research Arij Mohamad R. O. Chabrawi, André F. Ferreira, Carlos E. A. Silveira, Gustavo R. Oliveira, Marcelo M. V. Brandão, and Ricardo R. Meira. 


\section{ABSTRACT}

As a signatory to Durban III World Conference against Racism, Discrimination, Xenophobia and other forms of Intolerance, Brazil has committed itself to the enforcement of mechanisms to promote social equity. As a consequence, governmental programs have been implemented, aiming at the inclusion of Afrodescendents in higher education. Actually, the quantity of such students in the academy is minimal and does not relate to what can be observed in the general population. As an example of such endeavor, Universidade de Brasília (UnB) has started an Affirmative Action program in order to include a contingent of $20 \%$ of its freshman students as representatives of racial underprivileged groups. This policy started in August 2004. The present study aimed to investigate the perceptions of students and general public to this policy. An instrument, based partially on McConahay's (I986) Modern Racism scale, was administered to a sample of $3 \mathrm{I} 6$ students. A factor analysis (AF) extracted five factors, corresponding to $48 \%$ of the total variance explained. An Analysis of Variance (Anova) was performed to better understand the results, concerning both age and gender of the subjects. Results show that, although students demonstrated interest in the implementing of Affirmative Action programs, and are aware of the relevance of such procedures to the cultural and social structure of the community, they do not agree with their reasons or measures taken, or to the existence of the problem itself.

\section{KEYWORDS}

28 Affirmative action; Racism; Racism measurement; Social inclusion; Higher education.

\section{RESUMO}

Na qualidade de signatário da Conferência Mundial Contra o Racismo, Discriminação, Xenofobia e outras formas de Intolerância, o Brasil se comprometeu 
com mecanismos para promoção da igualdade. Como consequência, diversos programas governamentais foram concebidos, buscando a inclusão social de afrodescendentes na educação superior. De fato, a quantidade de tais estudantes na academia é mínima e não se aproxima do que pode ser observado na população como um todo. Como exemplo desse esforço, a Universidade de Brasília (UnB) começou um programa de ação afirmativa com o objetivo de incluir $20 \%$ de seus calouros como representantes dos grupos raciais minoritários. Essa política iniciou-se em agosto de 2004 . O presente estudo buscou investigar as percepções de alunos e do público em geral sobre tal política. Um instrumento baseado parcialmente na Escala de Racismo Moderno de McConahay (I986) foi administrado a uma amostra de $3 \mathrm{I} 6$ alunos. A Análise Fatorial (AF) extraiu fatores correspondentes a $48 \%$ da variância total explicada. Executou-se a Análise de Variância (Anova) para melhor compreensão dos dados no que se refere à idade e ao gênero dos sujeitos. Os resultados apontam que, apesar de os estudantes demonstrarem interesse no processo de implantação de programas de ação afirmativa e estarem conscientes da relevância de tais procedimentos para a estrutura social e cultural da comunidade, não existe concordância quanto às suas razões e medidas tomadas ou com a própria existência do problema.

\section{PALAVRAS-CHAVE}

Ação afirmativa; Racismo; Medidas de racismo; Inclusão social; Educação superior.

\section{INTRODUCTION}

The present study has the objective of discussing how Affirmative Action programs are perceived in a non-West country. Specifically, the perception of college students towards the implementation an Affirmative Action program in a large Brazilian university was investigated, and conclusions regarding the acceptance of such programs are drawn, apart from its implication to the understanding of racial dynamics in Brazil. As such programs can be seen as a political reaction to injustices against non-privileged groups in one society, it is important to, first, address some cultural and social aspects of the Brazilian society, in particular to what relates to its racial structure, such as discrimination and racism.

During the colonization process in Brazil, the Portuguese domination and enslavement of the native population led to bloodshed (RIBEIRO, I995). The decimation of the original inhabitants lasted centuries, being estimated that 
from an original population that might have reached from two to five million natives, now there exists just over 360,000 today, representing some $0.2 \%$ of the Brazilian population (IBGE, 2002).

Due to such constraints, forced by the European colonizers in the so-called workforce, the first African slaves were brought to Brazil in I538. In the following three centuries 3.5 million African slaves were brought to the country, frequently treated in appalling conditions, bought and sold as it pleased to their masters. For Ribeiro (I995), the country has a cultural division that originates from this social-economical history.

As a result of its wide territorial extension, Brazil is very heterogeneous in cultural terms, with different groups being formed by the European immigration and the African slavery commerce. Slavery in the country was abolished a little more than a century ago in Brazil (in I888). Yet, persons of African ancestry have historically suffered discrimination from people from different origins (HENRIQUES, 200I). This is mostly true when we consider that, in relation to racial issues, one of the most serious aspect of discrimination is the social and economic poverty that can be observed in most of the African descendants in the country.

Evolving to present days, this situation led to a perception of a racial stability in Brazil, which has been supported by what is known as the "racial democracy" consensus (SKIDMORE, I976). That is a concept somewhat complex, which refers to a national belief that Brazil is not a racist country, in particular due to its extensive Black ${ }^{2}$ population and its presence in the national cultural scenario. It is also believed that opportunities are equally presented to all citizens, leading to a situation where the difficulties due to racial questions are denied (SCHWARTZMAN, 2003). However, official data seems to dictate otherwise, as the White population receives better education, have higher incomes, and more health care and job opportunities than Blacks. Such issues in Brazil were listed by Unesco as a theme related to a large range of difficulties faced by the young Black population, such as social inequalities, violence and poverty (THOMPSON, 2000; HENRIQUES, 2000, 200I, 2002). The society in general has an inherited difficulty in coping with racist behaviors, and is not quite aware of their manifestations or effects. Considering this context, this study has the general objective of investigating the social impact of an Affirmative Action program directed towards Blacks in the higher education context, through the observation of college students' perception of the phenomena.

In order to achieve this objective, a Racism Scale was developed and tested in Brazil. An assumption was taken that two forms of racism co-exist in this 
context, named Classic and Modern Racism (MUMMENDEY; WENZEL, I999). While the first is characterized by the blatant expression of hostile behaviors related to a target group, the former presents itself in a rather subtle, less opened fashion. The differentiation on the expression of prejudice is a consequence of the institutionalization of norms that banned discrimination against underprivileged groups. The conception of alternative ways of expression of such beliefs is a consequence of such ruling (MCCONAHAY; HARDEE; BATTS, I98I; MCCONAHAY, I983; PETTIGREW; MEERTENS, I995), therefore allowing dominant groups to dodge these directives. This is frequently achieved by denial of prejudice, by attributing social and economical difficulties of minorities to internal factors (e.g. little effort or lack of discipline), which expanded from race into gender relations.

While the model of Classic Racism has focused on blatant racism, this perspective has examined the possibility that racism is also expressed more covertly. The reported racial attitudes of Whites changed dramatically in surveys between the I940s and the I980s (FISKE, I998), yet subtle indicators of White prejudice remain. Given the opportunity to help a Black person or a White person, Whites give less help and less helpful help to Blacks. Confronting the discrepancy between words and deeds, as well as examining the subtle indicators of prejudice led some scholars to wonder whether the dominant affect was not hatred, leading to aggression, but rather ambivalence and discomfort, leading to avoidance (MCCONAHAY, I983). One recognized theory which attempts to resolve this dilemma was also the one most oriented to individual differences: the Modern Racism Scale (MCCONAHAY; HOUGH, I98I) built on the related concept of symbolic racism. That is, because Whites were no longer comfortable expressing racism directly, they would express it instead by advocating traditional values and policy preferences that all happened to disadvantage Black people. By this token, opposition to busing, Affirmative Action and welfare were really attitudinal cover-ups for an underlying theme of anti-Black racism, for which these issues were symbolic. Thus, the Modern Racism Scale was designed to measure this symbolic form of racism as a stable individual difference. Modern racists believe that Blacks are gaining underserved status and attention, pushing themselves where they are not wanted, and that Blacks' anger is unreasonable because discrimination is no longer a problem. Following McConahay's work, Pettigrew and Meertens (I995) created a new subtle racism scale which was used in Europe, as well as the United States. Yet, no parallel measure that investigates the subtle opposition to AA policies was found in Brazil. The development of such measure is a secondary objective of this study. As it follows, the bases for the implementation of Affirmative Action programs are discussed, as well as the development of one program at a Brazilian university. 


\section{LITERATURE}

In recent years the discussion of the existence of this "tacit segregation" has re-surfaced and is reason for debate, gaining new grounds especially in what relates to education. It is now believed that generating learning opportunities to Black students through education may contribute to alter the racial distribution of Brazilian society as it regards to educational level, reflecting the experience of other countries where Affirmative Actions (AA) have been used as a mechanism to achieve social inclusion 3 . Fighting racial prejudice in the educational settings is expected to create conditions to a better understanding, bringing both sides together and encouraging the creation of new social groups that can better participate, and have a voice, in the society. Such expectation was stated by Cohn (I995, p. 2) in that "to foster a new orientation to policies, in a way of making them more evenly balanced and thus capable of contemplate the existing social diversity, is a confrontation to the inheritance of the country's social protection system".

Social inclusion programs are frequently related to economical needs of a group, frequently facing a situation of difficulty. These difficulties, in turn, violate the perception of equity within a society, which is inconsistent to the meritocracy ideology. This is the Brazilian case, where the recent economic evolution and stability presented similar consequences as observed in other countries. In short, that means lesser social mobility, broadening of social inequalities and differences (COHN, I995). A result of this situation is the increase in impoverishment, especially at the working classes or groups that are already underprivileged, as a direct consequence of the lack of creation of new jobs, not to mention the loss of the quality on the existing ones.

Due to its historical background and social evolution, the Brazilian educational system has been a source of social distortions, albeit initiatives to mitigate this situation - perhaps because of the lack of continuity of such proposals. Yet, as a result to policies implemented at different government levels, signs of an improvement can be noticed, especially in what relates to basic education. Recent statistics show that over $97 \%$ of the Brazilian children up to age I4 are enrolled in scholar activities (HENRIQUES, 2002), thanks to programs such as Bolsa Escola (Elementary-level Scholarships) and Renda Minima (Federal Govern-

Affirmative Action is understood as social policies pioneered by the USA as a mechanism aimed to present solutions to what Skidmore (1976) names as "the American dilemma" that is, the social and economical marginalization of the Afro-American. This definition encompassed later other ethnical minorities, women and persons with disabilities. To this author, AAs are interesting initiatives to attack the problem but are controversial proposal, as some groups may incorrectly understand that a place is being taken from a White person to be given to a Black one. 
ment Allowances), both aiming to provide financial assistance to families, as long as their children will attend regular classes.

The discussion now turns to the need of improving the quality of public education, providing better conditions to students, teachers, and making it possible to students to complete the basic education. However, Black population has not been equally benefited by these policies, as the situations inside schools still needs improvement. For instance, as studied by Cavalleiro (2000) the kind of attention that a child will receive from his-her teacher differs according to the child's race, (Black children do receive less attention and nurturing from teachers, when compared to White children). The effects of this action in the child's self-esteem and self-confidence are troublesome, negatively affecting the rest of the student's life.

Not surprisingly, the social gap that lingers in the classroom is represented in the scholastic performance. Evidence shows (IBGE, 2002; SHICASHO, 2002) that the performance differs between Blacks and Whites in Brazil, creating an obstacle to social inclusion of Black individuals that has not received the necessary attention until now. As a consequence, the number of Black students attending universities is much smaller than their actual representation in the general population. Besides the educational history, this fact is related to both social and historical reasons.

Notably, higher education is not available to all Brazilian students that may seek the continuity of their studies. Thus, certain State administrations started adopting measures to increase the participation of such students in undergraduate programs, by creating quotas for Blacks in public State universities. Some Federal universities followed this movement by taking similar AA measures. In this study we investigate part of the implementation process of such an intervention that started in August 2004 at the University of Brasilia, a large Federal university in the country. Although the overall procedures were designed to affect aspects of the organizational and social development, in the present study only the perception of such AA program was investigated.

\section{THE IMPORTANCE OF AN AFFIRMATIVE ACTION}

The latest Io years have observed a change in the discussion of the racial issues in Brazil. What was originally seen as a "problem" restricted to Afro-descendants, began to be understood as a matter that affects the society as a whole. If at the beginning of such discussion, ethnic-related non-governmental organizations were the sole supporters of ideas such as the Movimento Negro (Black movement), the actual stakeholders increased, and the discussion has broadened. However, 
the resistance to accept the consequences of the structural changes needed is still generating difficulties to the implementation of the AAs in some institutions.

Historically, the first measures to account for racial discrimination in Brazil were adopted in the legal field in the middle of the last century. The most relevant instrument adopted was the Afonso Arinos Law (I95I), which precludes imprisonment for persons convicted of racial or color discrimination. Two other legal instruments, the Caó Law (1985) and the Paim Law (1997), expanded the coverage of the former, setting longer imprisonment terms for discrimination on the basis of race, color, ethnicity, religion, or national origin, practiced directly and indirectly, in all terms (e.g. racist publications).

The Brazilian Constitution (1988) establishes as an attribution of the State the protection of native and Afro-Brazilian cultures, and those of other groups participating in the national process of civilization. This emphasizes two paramount aspects for the protection of cultural groups: the access of the group to its culture and its diversity, and the right of participation of persons in the creative process and expression of their own culture. As a result, cultural backgrounds were acknowledged, such as the recognition of African descendants living in quilombos (communities of resistance to slavery that were established when it was still a legal activity). Remnants of quilombos were given the right to ownership of the lands that were occupied by their descendants for the past five centuries.

In I995, the Federal Government established an Inter-Ministerial Working Group to propose actions to tackle racial discrimination and promote the social and economic integration of Afro-Brazilians. Later, in 200I, it established the National Council for the Combat of Discrimination, responsible for proposing, monitoring, and evaluating public policies for promoting equality and protection of rights of individuals, social and ethnic groups affected by racial discrimination. A significant result of the activities of this Group was the creation of an extensive proposal for the Federal Government to adopt AA measures, in recognition of the rights of the Black population. In the areas of education, diplomacy, and culture, such measures were taken through their respective Ministries, aiming to expand the access of Afro-Brazilians to universities, diplomatic corps, among other initiatives.

In such legal grounds, the foundations to a social shift were set. However, it is most relevant to consider the social implications of these movements. Citing Tajfel, Taylor and Moghaddam (I994, p. 5-6) point out that social change is:

[...] the subjective modes of structuring the social system in which the individual lives. It refers basically to his belief that he is enclosed within the walls of the social group of which he is a member; that he cannot move out of his own into another group in order to improve or change his position or his conditions of life. 
Such perception is also supported by Cuellar (I997) who states that it is not sufficient to condemn discrimination, and that is useless to make claims based on human rights and/or moral imperatives on such a matter. The problems caused by discrimination cannot be solved by judicial or technical measures only. Racism, even when presented in a surreptitious fashion, is not a marginal phenomenon: it develops whenever there is a social identity crisis. That is to say that the circumstances that help setting up a discriminatory environment, allied to the reproduction of discriminative models, hinder social mobility.

As described by Aberson (2003), such evolution is based in, at least, two different points of view: social justice and legitimacy, as a mean to social change. While the first can help to understand the effects of discrimination, which keeps a person or a group outside an organization or block the access to information, the legitimacy perspective consists in the adoption of procedures that, while battle this social obstacles, foster inclusion.

An important theoretical model to explain this dynamic is the realistic conflict theory (RCT), proposed by Sherif (I966). The theory states that intergroup conflict and co-operation are a result of responses to real or imagined group interests. It is based in three assumptions about behavior: a) people are selfish and will try to maximize their own rewards, b) conflict is the outcome of incompatible group interest, and c) the social psychological aspects of intergroup behavior are not determinants, but rather determined by compatibility or incompatibility of group interests. Relating RCT to the existing educational and social scenario in the country, it can be found a reasonable ground for conflict to arise, as there are limited resources in higher education as well as restrictions to funding. The interests of the different social groups are in dispute and, naturally, one of the groups is exercising control over such resources.

Furthermore, it is interesting to note that these resources are controlled by a White dominant group and so, if the situation and the perception of the problem are to be changed, the approach must take into consideration the reduction prejudice through intergroup contact. This situation relates to what became known as Gordon Allport's Contact Hypothesis, which states that prejudice is a direct result of generalizations based on incomplete or mistaken information, about a group of people. Thus, contact between the groups, when conducted properly, should lead to better interactions. The Contact Hypothesis is based in the assumption that that prejudice may be reduced as one learns more about the group or groups toward whom the discriminating behaviors or perceptions are driven. That said, it is coherent to believe that "Affirmative Action can be considered as a tool that may be used as an instrument to create the necessary conditions to a transformation in society" (SOARES, 2000, p. 39). 
Based on this ideology, the University Brasilia (UnB) proposed a system to foster the inclusion of Blacks among its students. This initiative is of great relevance in the Brazilian education context, due to the visibility of UnB, recognized as one of the leaders in its field, and because of its proximity to high-rank politicians. More precisely, this large educational institution operates at the political capital of the country, as well as one of the first to propose such an endeavor.

The proposal of UnB was to hold $20 \%$ of undergraduate openings to Black students each semester, for a period of ten years, starting at the second semester of 2004. This refers to a number of nearly 400 students per semester. A support program is also planned, aiming to give the necessary attention to such students, in an effort to prevent the drop off courses (CARVALHO; SEGATO, 2002) such as Education, Psychology, and Social Services.

It was expected that newcomers would face some adversities or difficulties in their participation in campus life. As pointed by Kent (1996), the university is a representation of society and, as such, is subjected to similar problems, being the nature of race relations on campus just one of this instances. Fisher and Hartmann (I995) presented a study on personal experiences related to racial prejudice. The research was also conducted in university campus with a White majority, pointed out that, whilst both groups (Black and White students) had similar opinions on the importance of interracial experiences between students, social segregation was still reported as the norm on campus. Other findings support the existence of a link between racial prejudice and other prejudicial attitudes. Qualls, Cox, and Schehr (I992) observed that individuals who showed racially-biased opinions, were also prone to attitudes against gender, having stereotypical gender role views.

One of the common criticisms to AA programs in universities is that the acceptance of underprivileged students would jeopardize the selection of betterprepared (often non-Black) students. The UnB system considers the use of a mandatory minimal punctuation at the selection exam, meaning that, even though the protected student's grades may be lower than the non-protected ones, the first group still needs to demonstrate the same basic skills as the later, in order to be considered eligible to entering the institution. If the openings available to the program students are not filled out, the remaining positions will be assigned to non-protected candidates.

Another challenge of this AA program was to define the race of the student. Unlike the situation observed in some countries such as the United States, the UnB program allows postulants to be classified by their own judgment on his or her ethnicity. This self-classification is then evaluated by a commission that, prior to selection, decides whether the candidate is eligible of not to enter the program. This is indeed a tricky situation, were a misjudgment can be very dangerous both to candidate as well as to all the selection system. 
Last, critics of the program state that it is likely that Black middle class students, that normally would not be covered by the program, would benefit from this strategy, in detriment of other Black students from less privileged backgrounds. That is to say that the most needed students would still not be treated fairly.

Even though these concerns are not a novelty when AA programs are created, a number of studies have demonstrated that diversity-increasing programs through AA procedures have results of high social relevance. For instance, Lefevre (2003) points to the fact that such initiatives take into consideration that there are no barriers to be imposed to non-participants that are better prepared. Johnson and Lollar (2002) suggested that students enrolled in such programs are more prone to participate in political and social activism, as well as present greater awareness of any inter-relations between different cultures. Konrad and Janet Spitz (2003) found that traditionalistic attitudes related to gender and race are good predictors of positive or negative perceptions over AA programs. Finally, Aberson (2003) demonstrated that ethnical aspects mediate the perception of the benefits of such measures, being responsible to greater commitment of the participants.

Until now we have outlined some of the characteristics of UnB program, as well as aspects that may play a role as a background to it. In order to assess the students' perceptions of the program, the present exploratory study was developed. It important to state the study was made prior to the programs' implementation.

\section{METHOD}

Based on the assumption that much of the perception about a university's AA proposal is biased (either knowingly or unknowingly), the study searched to examine the students views in relation to their knowledge of the actual AA strategy, as well as their attitudes towards the protected Black group. The aspects focused by the study are the Modern Racism perspective, and its influence on the sensibility of the individuals to the problem, as well as to the program adopted.

The main areas of inquiry are related to a) subjects perceptions on the adequacy of the AA as a mean of retribution/equality to underprivileged groups, and b) their feelings on discrimination and Modern Racism. To that end it was first developed a background questionnaire (I7 questions) that inquired on the knowledge of the implementation of the AA at the university, including elements related to its possible consequences, students' knowledge of the proposed AA methodology, and their opinion regarding the life conditions of Black citizens in the country. It was also developed a Modern Racism Scale, based on an 
adaptation of McConahay (I986) original scale (I2 questions). Both instruments were developed in Portuguese, with the help of Focus Groups, structured on basis of race, gender, age, and being a student at UnB or not.

The questionnaires used a Likert-like scale (7 points varying from totally agree "I" to totally disagree " 7 "). The twenty-nine items composed the final instrument, and an open-ended question regarding the subject's opinion associated to the identification of ethnical background was included: What is the most legitimate way of identifying race? At the end of the questionnaire, the subject was asked to respond to demographic data, such as age, gender, and major.

\section{PROCEDURES}

A sample was proposed considering the distribution of students at the university, according to their proportion in campus. It was expected that a part of the sample would be composed of off-campus high-school students as well, in a total of 400 intended subjects. Researchers were assigned to different schools (Health, Human Sciences, Exact Sciences etc.) according to the representation of each school in the general population. No error estimative was computed for the sample. Different times in all class hours of day and night were included, in an attempt to represents the proportion of students attending different schedules.

Research procedures were conducted during the months of May and June 2004. After clearing outliers and other response errors, final data were collected from $3 \mathrm{I} 6$ subjects, $89 \%$ from university background and II\% from high school level. Subjects were volunteers, asked freely to participate in a study related to the AA proposed by the university. Upon positive answer, researchers followed a formal protocol, in order to reduce experiment bias. Subjects were asked to present their first response, which should be the most sincere, that no identification was needed and that their information would be treated with confidentiality. It took from to to I5 minutes to each subject to complete the survey.

\section{RESULTS AND ANALYSIS}

The final subject distribution was 36\% from Human Sciences (e.g., Sociology, History, Business), 36\% Exact Sciences (e.g., Math, Physics, Engineering), II\% Biological Sciences (e.g., Biology, Veterinary); 6\% Health Sciences (e.g., Medicine) and ıा\% from high school. It was observed that $55 \%$ subjects were male; the mean age was 22 years $(\mathrm{SD}=6)$. 
A factor analysis was performed and five factors were extracted using Principal Axis Factoring and Varimax Rotation with Kaiser Normalization. The rotation was selected in order to simplify the number of variables with high loadings in each factor. The Kaiser-Meyer-Olkin (KMO) measure of sampling adequacy retuned a value of 0.82 , confirming that the matrix is factorable. Factor loading values in the interval of $-0.3 \mathrm{I}$ and 0.29 were excluded from the analysis. The resulting structure is responsible to $48 \%$ of explained variance, and the confidence indexes (Cronbach's Alpha) were all above 0.7 (varying from 0.79 to $0.7 \mathrm{I}$ ) to all factors.

The overall integrity of the questionnaire was maintained; however some questions imagined to be more suited to different dimensions presented themselves in a different fashion than expected. The factors items - all in Portuguese, as well as their loadings, can be seen at Appendix I.

The resultant factors were interpreted as follows:

I. Perceptions and knowledge about Affirmative Action: Related to both the university proposal and other discussions on the subject.

2. Racism (modern racism): Associated to the perception of racism, segregation and discrimination, as well as consequences of its existence.

3. Effects of Affirmative Action in society: Related to expected changes in society and people's discriminative behavior linked to discrimination.

4. Perceptions about racial group: Associated to the perception of the life aspects of the racial group and the evolution of the racial question.

5. Racism and family relations: Related to the effect of discrimination in the formation of friendship or family ties.

By analyzing the subject's answer pattern it was noted that, when answering specific racial related questions on Factor 2, a lower level of racial bias was identified. However, the same subjects rejected the questions presented on Factor 4, indicating that such students would be more likely to express covert, rather than overt discrimination.

It was examined whether there was a difference by sex or age in the perceptions by students of racial segregation in two contexts: a) the level of manifest or subtle racism and b) the knowledge of the description of the AA proposed. In this context the questions were presented in two levels, (i.e. modern racism and structure of the racial group needs, according to the subject's perception). An analysis of variance (Anova) was executed in order to determine if a) the independent effects of age and sex (i.e., the two main effects) and b) the existence of effects of interaction between sex and age and the perception of racism and fairness. 
Sex has a significant $\left(F_{(\mathrm{I}, 315)}=24 \mathrm{I} .83 ; p<0.01\right)$ main effect for Factor I, indicating that there is greater perception of unfairness or injustice inherent to the social system by males. Factor 5 presents the same level of significance, but indicates that females felt more strongly that the racial issues were important when dealing to racism and family/social relations.

The variable age was categorized in intervals of five years, starting from $\mathrm{I} 5$ (I5 to I9, 20 to 24 and so on). It has presented a significant effect $\left(F_{(\mathrm{I}, 3 \mathrm{I} 2)}=139.5 \mathrm{I}\right.$ $p<0.01$ ) for Factor 3 that relate to social change as a consequence of AA. That is to say that the younger subjects felt that it is more likely that as a consequence of the program there may be a change on the condition of the underprivileged group. No results were found for iterations between sex and age.

\section{CONCLUSION}

In recent years, attempts studies of racial tolerance on college campuses have met with mixed results. Be as it may, the nature of racial debate on campus indicate that the university is a microcosm of society and faces the same nature of difficulties (KENT, I996). The present study examined the relations existing among sex, age and some aspects of the discrimination and AA effects. The instrument produced five factors that were interpreted and results show that, however subjects manifest an understanding of the necessity for equality and awareness about the condition of the Racial group in question, and even about the justice of an endeavor to correct a secular social distortion, there is no great enthusiasm or much belief in that the chosen strategy is the most fair one.

When contrasting the subject's answers on factors 2 and 4 it is noted a certain degree of discomfort with one's perception to their behavior and understanding of its causes. That is to say that, the Brazilian racial discrimination style "racial democracy" is still an obstacle to the implementation of the AA. Although a low level of racial bias was identified, the subjects rejected the questions presented, indicating that they would be more likely to express covert, rather than overt discrimination.

The Anova findings support conclusions from other studies on the area (e.g. QUALLS; COX; SCHEHR, I992) that, despite the efforts from civil legislation and other initiatives, racism remains a social stigma in society and universities are not immune to it. As indicated by Kent (I996, p. 45) universities can no longer "pretend to offer a refuge from the swirling antagonisms of a highly racialized society". Additionally, students are aware of this "subtle racism," perceiving it in the policies, that should take this into consideration. 
The analysis also showed that there was a significant relationship between sex and discriminatory behavior in five questions, confirming the findings in previous studies that universities are not immune to racism, though the reported perception of racial bias on this campus was generally low. Unfortunately, racism and discrimination seem to still keep its roots, now in different ways. As shown by McConahay (I986), "old-style racism" has been replaced by a much more cautious "modern racism" and this may point that there is still much to do prior to make AA, when related to racial issues, a large instrument for social justice.

As limitations to the research, as mentioned before, the sample in this study consisted of subjects from one specific geographic area, where the AA was being implemented at a major university. Even more, the subjects were invited to answer the questions and these facts hinder the generalization of the findings, once the fact that subjects were volunteers point to some degree of interest in the matter. Other limitations of this study is that the questionnaire was tailored to measure various manifestations of racial bias, combined to perceptions of fairness and knowledge of AAs and so reducing the conditions to analyze structural factors of discrimination. Finally, the question on the best form to identify race was not taken into analysis in this study due to the great difficulty in categorizing it. However, provided some insights on how complex this effort is.

\section{REFERENCES}

ABERSON, C. Support for race-based affirmative action: self-interest and procedural justice. Journal of Applied Social Psychology, Hoboken, NJ, n. 33, p. I2-I4, 2003.

BRASIL. Constituição da República Federativa do Brasil. Brasília, DF: Senado, I988.

Lei $n^{\circ}$ I.390, de 3 de julho de I951. (Lei Afonso Arinos). Diário Oficial [da] República Federativa do Brasil, Rio de Janeiro, RJ, p. I80-235, 3 jul. I95I.

Lei n. ${ }^{\circ}$ 7.437, de 20 de dezembro de I985. (Lei Caó). Diário Oficial [da] República Federativa do Brasil, Brasília, DF, Seção I, p. 295-309, 20 dez. 1985.

Lei n. ${ }^{\circ}$ 9.459, de I3 de maio de I997. (Lei Paim). Diário Oficial [da] República Federativa do Brasil, Brasília, DF, p. 392-393, I4 maio 1997.

CARVALHO, J.; SEGATO, R. L. Uma proposta de cotas para estudantes negros na Universidade de Brasília. Brasília: Conselho de Pesquisa, Ensino e Extensão (Cepe), Universidade de Brasília, 2 mar. 2002. Manuscrito.

CAVALLEIRO, E. Do silêncio do lar ao silêncio escolar: racismo, preconceito e discriminação na educação infantil. São Paulo: Humanitas, Contexto, 2000.

COHN, A. Políticas sociais e pobreza no Brasil. Planejamento e Políticas Públicas, Brasília, DF, n. I2, jun./dez. I995.

CUELLAR, J. P. (Org.). Nossa diversidade criadora: relatório da Comissão Mundial de Cultura e Desenvolvimento. Brasília: Unesco; Campinas: Papirus, I997.

FISHER B. J.; HARTMANN, D. J. The impact of race on the social experience of college students at a predominantly white university. Journal of Black Studies. v. 26, n. 2, p. II7-I33, I995. 
FISKE, S. T. Stereotyping, prejudice, and discrimination. In: GILBERT, D. T.; FISKE, S. T.; LINDZEY, G. (Org.). The Handbook of Social Psychology. New York: McGraw-Hill, I998. p. 357-4II. HENRIQUES, R. Desnaturalizar a desigualdade e erradicar a pobreza: por um novo acordo social no Brasil. In: Desigualdade e pobreza no Brasil. Rio de Janeiro: Ipea, 2000. p. I-I8.

Desigualdade racial no Brasil: evolução das condições de vida na década de 90 . Rio de Janeiro: Ipea, 200I.

Raça e gênero nos sistemas de ensino: os limites das políticas universalistas na educação.

Brasília: Unesco, 2002.

IBGE. Censo 2000 Resultados Preliminares. Rio de Janeiro, IBGE, DPE, Deren, 2002.

JOHNSON, S. M.; LOLLAR, X. L. Diversity policy in higher education: the impact of college students' exposure to diversity on cultural awareness and political participation. Journal of Education Policy, London, n. 3, p. 305-321, I7 June 2002.

KENT, N. J. The new campus racism: What's going on? Thought \& Action, Washington, DC, v. I2, n. 2, p. 45-57, 1996.

KONRAD, A.; JANET SPITZ, A. M. Explaining demographic group differences in affirmative action attitudes. Journal of Applied Social Psychology, Hoboken, NJ, n. 33, p. 16-25, 2003.

LEFEVRE, J. The value of diversity: a justification of affirmative action. Journal of Social Philosophy, Hoboken, NJ, v. 34, n. I, p. I25-I34, 2003.

MCCONAHAY, J. B. Modern racism and modern discrimination. Personality and Social Psychology Bulletin, Hoboken, NJ, n. 9, p. 551-558, I983.

Modern racism, ambivalence and the modern racism scale. In: DOVIDIO, J. F.; GAERTNER, S. L. (Ed.). Prejudice, discrimination and racism. New York: Academic Press, I986. p. 9I-I26. MCCONAHAY, J. B., HARDEE, B. B.; BATTS, V. Has racism declined in America? It depends on who is asking and what is asked. Journal of Conflict Resolution, v. 25, p. 563-579, I98I.

MCCONAHAY, J. B.; HOUGH JR., J. C. Symbolic racism. Journal of Social Issues, v. 32, n. 2, p. 26-45, I976.

MUMMENDEY, A.; WENZEL, M. Social discrimination and tolerance in intergroup relations: reactions to intergroup difference. Personality and Social Psychology Review, Hoboken, NJ, n. 3, p. I58-I74, I999.

PETTIGREW, T. F.; MEERTENS, R. W. Subtle and blatant prejudice in Western Europe. European Journal of Social Psychology, Hoboken, NJ, n. 25, p. 57-75, I995.

QUALLS, R. C.; COX. M. B.; SCHEHR. T. L. Racial attitudes on campus: are there gender differences? Journal of College Student Development, Massachusetts, PA, n. 33, p. 524-530, I992.

RIBEIRO, D. O povo brasileiro: a formação e sentido do Brasil. São Paulo: Companhia das Letras, I995.

SANT'ANNA. W. Desigualdades étnico/raciais e de gênero no Brasil: as revelações possíveis do IDH e do IDG. Jornal da Rede Saúde, n. 23, 2000.

SCHWARTZMAN, S. Cor raça e origem no Brasil. Disponível em: <http://www.airbrasil.org.br/ Portugues/LinksExternos/frameSSchwartzman.html>. Acesso em: 2I out. 2003.

SHERIF, M. Group conflict and co-operation: their social psychology. London: Routledge \& Kegan Paul, I966.

SHICASHO, S. T. (Org.). Desigualdade racial: indicadores socioeconômicos - Brasil. I99I-200I. Rio de Janeiro: Ipea, 2002. I CD-ROM 
SKIDMORE, T. E. Preto no Branco: raça e nacionalidade no pensamento brasileiro. Rio de Janeiro: Paz e Terra, I976.

SOARES, V. As ações afirmativas para mulheres e no mundo do trabalho no Brasil. In: BENTO, M. A. Ação afirmativa e diversidade no trabalho - desafios e possibilidades. São Paulo: Casa do Psicólogo, 2000.

TAYLOR, D.; MOGHADDAM, F. Theories of intergroup relations: international social psychological perspectives. 2. ed. New York: Praeger, I994.

THOMPSON, A. A. Continuidade das práticas de parceria no combate à exclusão social. In: CARDOSO, R.; FRANCO, W. (Org.). Estratégias inovadoras de parceria no combate à exclusão social. Brasília: Unesco, 2000.

\section{APPENDIX}

\section{FACTOR STRUCTURE}

\section{LOADINGS AND CONFIDENCE INDEX TO THE QUESTIONNAIRE}

\begin{tabular}{c|l|c|c|c|c|c|}
\hline \multicolumn{1}{|c|}{ ITEM } & & \multicolumn{3}{|c}{ FACTOR } \\
\hline POSITION & QUESTIONS & 1 & 2 & 3 & 4 & 5 \\
\hline 8 & $\begin{array}{l}\text { O sistema de quotas perpetua o racismo no } \\
\text { Brasil. }\end{array}$ & 0.76 & & & & \\
\hline 11 & $\begin{array}{l}\text { O sistema de quotas coloca em questão a } \\
\text { capacidade intelectual dos negros. }\end{array}$ & 0.60 & & & \\
\hline 1 & $\begin{array}{l}\text { É compreensível que os negros estejam } \\
\text { descontentes com a falta de oportunidades no } \\
\text { ensino. }\end{array}$ & 0.61 & & & \\
\hline 7 & $\begin{array}{l}\text { Eu sou favorável ao sistema de quotas da UnB. } \\
\text { Os negros se sentirão inferiorizados pelo sistema } \\
\text { de quotas. }\end{array}$ & -0.58 & 0.58 & & & \\
\hline 17 & $\begin{array}{l}\text { O sistema de quotas irá desestimular os negros a } \\
\text { estudarem para entrar na UnB. }\end{array}$ & 0.51 & & & \\
\hline 4 & $\begin{array}{l}\text { O sistema de quotas é uma maneira de se fazer } \\
\text { justiça social. }\end{array}$ & -0.49 & & & \\
\hline 9 & $\begin{array}{l}\text { A igualdade de oportunidade deve começar pelo } \\
\text { ensino fundamental e não pelo ensino superior. }\end{array}$ & 0.35 & & & \\
\hline
\end{tabular}


LOADINGS AND CONFIDENCE INDEX TO THE QUESTIONNAIRE (Continuation)

\begin{tabular}{|c|c|c|c|c|c|c|}
\hline ITEM & & \multicolumn{5}{|c|}{ FACTOR } \\
\hline POSITION & QUESTIONS & 1 & 2 & 3 & 4 & 5 \\
\hline 10 & $\begin{array}{l}\text { No momento do ingresso na universidade, } \\
\text { é necessário privilegiar as classes menos } \\
\text { favorecidas. }\end{array}$ & -0.32 & & & & \\
\hline 16 & $\begin{array}{l}\text { Com o sistema de quotas, os brancos irão julgar } \\
\text { que os negros estão ocupando suas vagas na } \\
\text { UnB. }\end{array}$ & 0.30 & & & & \\
\hline 20 & É fácil entender a raiva dos negros neste país. & & 0.56 & & & \\
\hline 12 & $\begin{array}{l}\text { É compreensível que os negros estejam } \\
\text { descontentes com a falta de oportunidades no } \\
\text { mercado de trabalho. }\end{array}$ & & 0.54 & & & \\
\hline 22 & $\begin{array}{l}\text { Os negros estão exagerando muito na sua luta } \\
\text { por direitos iguais. }\end{array}$ & & -0.52 & & & \\
\hline 21 & $\begin{array}{l}\text { Existem negros que não têm empregos ou } \\
\text { perdem promoções por causa de discriminação } \\
\text { racial. }\end{array}$ & & 0.50 & & & \\
\hline 3 & $\begin{array}{l}\text { Os negros devem superar o preconceito sem } \\
\text { apoio, como aconteceu com outros grupos. }\end{array}$ & & -0.49 & & & \\
\hline 27 & $\begin{array}{l}\text { A integração racial é um importante passo para a } \\
\text { democracia no Brasil. }\end{array}$ & & 0.47 & & & \\
\hline 28 & $\begin{array}{l}\text { É uma boa ideia que as crianças frequentem } \\
\text { escolas que têm a mesma proporção de negros e } \\
\text { brancos. }\end{array}$ & & 0.44 & & & \\
\hline 2 & $\begin{array}{l}\text { A discriminação contra negros não é um } \\
\text { problema no Brasil. }\end{array}$ & & -0.40 & & & \\
\hline 26 & $\begin{array}{l}\text { As leis que impedem a discriminação e favorecem } \\
\text { a integração racial são desnecessárias no Brasil. }\end{array}$ & & -0.34 & & & \\
\hline 14 & $\begin{array}{l}\text { O sistema de quotas trará mudanças positivas } \\
\text { para situação dos negros nas próximas gerações. }\end{array}$ & -0.38 & & 0.76 & & \\
\hline
\end{tabular}


LOADINGS AND CONFIDENCE INDEX TO THE QUESTIONNAIRE (Conclusion)

\begin{tabular}{|c|c|c|c|c|c|c|}
\hline \multirow{2}{*}{$\frac{\text { ITEM }}{\text { POSITION }}$} & \multirow[b]{2}{*}{ QUESTIONS } & \multicolumn{5}{|c|}{ FACTOR } \\
\hline & & 1 & 2 & 3 & 4 & 5 \\
\hline 13 & $\begin{array}{l}\text { O sistema de quotas conseguirá reduzir a } \\
\text { desigualdade entre brancos e negros no mercado } \\
\text { de trabalho. }\end{array}$ & -0.44 & & 0.61 & & \\
\hline 15 & $\begin{array}{l}\text { A desigualdade social entre brancos e negros no } \\
\text { Brasil é responsabilidade do Estado. }\end{array}$ & & & 0.38 & & \\
\hline 6 & $\begin{array}{l}\text { Eu estou familiarizado com o sistema de quotas } \\
\text { da UnB. }\end{array}$ & & & 0.35 & & \\
\hline 29 & $\begin{array}{l}\text { Em geral, negros são mais inteligentes que } \\
\text { brancos. }\end{array}$ & & & & 0.59 & \\
\hline 18 & $\begin{array}{l}\text { Nos últimos anos, os negros têm tido mais } \\
\text { sucesso econômico do que eles merecem. }\end{array}$ & & & & 0.59 & \\
\hline 19 & $\begin{array}{l}\text { Nos últimos anos, o governo e a mídia escrita } \\
\text { têm demonstrado mais respeito pelos negros do } \\
\text { que eles merecem. }\end{array}$ & & & & 0.50 & \\
\hline 24 & $\begin{array}{l}\text { Se uma família negra que tem a mesma renda e } \\
\text { nível de educação que você mudasse para a(o) } \\
\text { casa (apartamento) ao lado, você se importaria? }\end{array}$ & & & & & 0.73 \\
\hline 25 & $\begin{array}{l}\text { Você se importaria se um membro da sua família } \\
\text { tivesse uma forte amizade com uma pessoa } \\
\text { negra? }\end{array}$ & & & & & 0.69 \\
\hline 23 & $\begin{array}{l}\text { Negros não conseguem boas casas porque } \\
\text { pessoas brancas não alugam ou vendem essas } \\
\text { casas para eles? }\end{array}$ & & & & & 0.41 \\
\hline \multicolumn{2}{|c|}{ Eigenvalue } & 5.9 & 3.7 & 2.1 & 1.8 & 1.4 \\
\hline \multicolumn{2}{|c|}{$\%$ of explained variance } & 20.0 & 12.5 & 6.4 & 4.9 & 4.3 \\
\hline \multicolumn{2}{|c|}{ Cronbach's Alpha } & 0.79 & 0.76 & 0.77 & 0.71 & 0.75 \\
\hline
\end{tabular}

Note: Values below .30 exist and were suppressed from the table to simplify structure visualization. 